\title{
Entrepreneurial Passion Development: The Interplay between Heuristic Thinking and Pedagogical Experience during Entrepreneurial Learning Process
}

\author{
(Pembangunan Keghairahan Keusahawanan: Interaksi di antara Pemikiran Heuristik dan Pengalaman \\ Pedagogi semasa Proses Pembelajaran Keusahawanan)
}

\author{
Muhammad Nizam Zainuddin \\ (Faculty of Management, Multimedia University) \\ Dzulkifli Mukhtar \\ (Faculty of Entrepreneurship and Business, Universiti Malaysia Kelantan) \\ Norhafizah Abu Hasan \\ Mohd Helmi Ali \\ (Faculty of Economics and Management, Universiti Kebangsaan Malaysia)
}

\section{ABSTRACT}

The underlying objective of an entrepreneurship education programme (EEP) is to facilitate students to becoming more passionate about entrepreneurship. This is done through the provision of a profound pedagogical learning experience while undergoing the entrepreneurial learning process. However, despite the rapid proliferation of EEP as the mainstream academic offering, previous literature argues that the current EEP delivery lacks the rigour and efficacy to provide a pedagogical experience that suits different personal identities that the students bring along into the classroom; thus, affecting their passion for entrepreneurship. In light of this, we review extensive literature related to entrepreneurial learning process, entrepreneurship education as well as the development of a passion for an activity. We also propose a theoretical framework of what may be missing in the current setup. We focus our discussion on the micro-foundation of the entrepreneurial learning process that occurs deep in the cognitive structure of individuals. Through the narrative literature review approach, we found that the lack of depth while the students validating their personal identity with the entrepreneurial learning activity affects the development of their passion for entrepreneurship. We offer refreshing insights into the importance of heuristic thinking, which embodies students' personal identity, and its interplay with the pedagogical experience during the entrepreneurial learning process. This is crucial in the promotion of a strong sense of identification with the entrepreneurial-related activity and deep affinity towards entrepreneurship. By recognising this missing element and linkage, the students will feel that their unique signature strength is being more appreciated, thus triggering a more intense reaction towards the learning stimuli. This is because they feel the profound recognition of their worthiness in the social circle as well as stronger belief about the mutual benefit between entrepreneurship and their ongoing personal life quest; which consequently allows their entrepreneurial passion to be further developed. This paper contributes to the underpinning insight of how entrepreneurial passion is developed, the way it can influence the interest of learning entrepreneurship in EEP and encourage the students to become more passionate about entrepreneurship.

Keywords: entrepreneurship education; entrepreneurial passion; entrepreneurial learning; pedagogical experience; heuristic thinking

\section{ABSTRAK}

Objektif asas sesebuah program pendidikan keusahawanan (РPK) adalah untuk mempermudahkan para pelajar untuk menjadi lebih ghairah tentang keusahawanan dengan menyediakan pengalaman pembelajaran pedagogi yang sangat bermakna ketika sedang menjalani proses pembelajaran keusahawanan. Walaupun demikian, meskipun PPK dengan begitu pesatnya ditawarkan sebagai salah satu program akademik arus perdana, literatur terdahulu mendalilkan bahawa penyampaian PPK semasa tidak mempunyai keupayaan dan keberkesanan untuk memberikan pengalaman pedagogi yang dihasratkan kerana ia tidak selari dengan kepelbagaian identiti peribadi yang yang dibawa oleh para pelajar ke dalam bilik kuliah yang berupaya menjejaskan keghairahan mereka ke atas keusahawanan. Oleh yang demikian, kami telah mengkaji semula secara mendalam literatur yang merangkumi proses pembelajaran keusahawanan, pendidikan keusahawanan serta pembangunan keghairahan untuk sesuatu aktiviti dan kemudian mencadangkan rangka kerja teoritikal yang menjelaskan apakah yang berkemungkinan hilang dalam penyampaian semasa PPK. Kami telah memfokuskan perbincangan kami mengenai asas mikro proses pembelajaran keusahawanan yang berlaku di dalam struktur kognitif individu. Melalui pendekatan ulasan literatur naratif, kami mendapati bahawa ada kekurangan yang mendalam ketika para pelajar cuba mengesahkan identiti peribadi mereka dengan aktiviti pembelajaran keusahawanan dan ini telah mempengaruhi pembangunan keghairahan mereka terhadap keusahawanan. Kami menawarkan pemahaman yang baru tentang kepentingan pemikiran heuristik, yang secara separa sedar mewakili identiti peribadi para pelajar serta interaksinya dengan pengalaman pedagogi semasa proses pembelajaran keusahawanan yang begitu penting dalam 
mempromosikan deria pengenalan yang kuat dengan aktiviti yang berkaitan dengan keusahawanan dan juga suatu perasaan pertalian yang mendalam terhadap keusahawanan. Dengan mengiktiraf elemen dan interaksi yang hilang ini, pelajar akan merasakan bahawa kekuatan dan kelebihan unik mereka lebih dihargai, justeru itu mencetuskan reaksi yang lebih kuat terhadap alat rangsangan pembelajaran oleh kerana mereka lebih merasakan pengiktirafan yang bermakna tentang kelayakan mereka di dalam sesebuah lingkaran sosial berserta perasaan kepercayaan semakin mendalam tentang kepentingan bersama di antara keusahawanan dan pencarian berterusan kehidupan sejahtera para pelajar, yang seterusnya membolehkan keghairahan keusahawanan untuk terus berkembang. Makalah ini menyumbang kepada pemahaman yang mendasari bagaimana keghairahan keusahawanan dimajukan, cara ia dapat mempengaruhi minat dalam mempelajari keusahawanan di dalam PPK dan menjadikan pelajar lebih ghairah tentang keusahawanan.

Kata kunci: pendidikan keusahawanan; keghairahan keusahawanan; pembelajaran keusahawanan; pengalaman pedagogi; pemikiran heuristik.

\section{INTRODUCTION}

The underlying objective of an entrepreneurship education programme (EEP) is to facilitate the students to becoming more passionate about entrepreneurship, which could be attained when the students come into contact with a profound pedagogical entrepreneurship learning experience. It is suggested that this profound pedagogical experience could be achieved through a successful behavioural integration between students' personal identity and activity in hand (Vallerand et al. 2003), which occurs deep in their micro-foundation cognitive structure (Krueger 2007, 2009). Following Vallerand (2008), a profound learning experience is also suggested to be the antecedent for the development of entrepreneurship passion from its initial contact point (i.e. activity selection) to the state when the students feel that the activity is consonant with their personal identities (i.e. behavioural integration). During this condition, the students will feel that the subsequent entrepreneurship learning sessions are becoming more fascinating and meaningful to them. This will then result in the investment of their personal resources (e.g. time, money, etc.) in learning and more information about entrepreneurship is sought.

In the meantime, since its inception in the institutes of higher learning, EEP has undergone multiple updates in its delivery setup (Pittaway \& Cope 2007a; Richardson \& Hynes 2008; Fayolle \& Gailly 2008; Mwasalwiba 2010; Fayolle 2013). These are generally done as responces to the constructive suggestions made by scholars in making EEP more relevant to the multiple stakeholders. As a result, the recent EEP delivery has been spotted to incorporate the experiential learning element, which is mainly designed to emulate the real-world entrepreneurship practice by using contemporary business and management methods such as creative-problem solving, design thinking and business simulation (Neck \& Greene 2011; Rae 2004; Pittaway \& Cope 2007a; Pittaway et al. 2015). It is suggested that the notion of introducing experiential learning in the EEP delivery be aligned with the natural process of entrepreneurial learning agency. Cope (2005) argues that developing a process to educate entrepreneurship to a mass audience should not be operated in isolation, rather it should be centrally related to the occurrence of specific processes in entrepreneurial learning. This is because learning development requires support from certain context to enable the intrinsic social process of learning occur. Winkel (2013: 313) highlights on the importance of having the involvement of many entities on the delivery of EEP in creating a suitable experience for the students:

Promising because it presents a unique opportunity to conjure the notion of a collective effort between groups of students and their educator; as a domain which uniquely engages students in experiential learning.

However, despite the rapid proliferation of EEP as the mainstream academic offering by the institutes of higher learning, the efficacy of EEP delivery in facilitating the students to becoming more entrepreneurial through the 'tailor-made entrepreneurial experience' is being critically questioned by scholars (Bae et al. 2014; Piperopoulos \& Dimov 2014; Volery et al. 2013; Rideout \& Gray 2013; Duval-Couetil 2013). They strongly argue that the current EEP delivery lacks the rigour and efficacy to deliver a pedagogical experience that suits the rich diversity that exists in the classroom such as the unique personal identity that the students bring along with them into the EEP context. Personal identity, the self-image that concerns with personal worth in which individuals hold critical to self-concepts (Brewer 1991) acts as an anchor to the secondary identities that the students have such as professional identity, youth identity, adult identity, parent identity and others. It is also proposed that it is very influential in affecting the way students respond to new entrepreneurial knowledge, which could then affect their pedagogical experience while entrepreneurship is learned (Ollila et al. 2012; Ollila \& Middleton 2013; Donnellon, Ollila \& Middleton 2014). More importantly and not surprisingly, the diversity issue has been identified by Vanevenhoven (2013) as the main reason that causes the contradictory findings in the previous EEP outcomes' studies (see: Martin, McNally \& Kay 2013; Bae et al. 2014; Unger et al. 2011). It is argued that EEP delivery fails to acknowledge that the students may have different motivations to enrol into EEP, starting the EEP with different bases of knowledge and experience, and having differences in free access to different resource networks. Therefore, the main concern that relates to the above discussion is, how these diverse students' personal identities would impact their pedagogical experience 
while undergoing the situated entrepreneurial learning process.

Motivated by the shortfall of the current EEP delivery, this paper intends to explore the way EEP delivery could be further improved. This is done by identifying, locating and proposing what may be absent in the current setup. Through the initial discussion, we clearly identify that there are two major issues that influence students' pedagogical entrepreneurial learning experience in the current EEP setup, namely: (1) the students actually bring their unique personal identity into the classroom and (2) there is a strong connection between identity and activity, which could lead to a profound entrepreneurial learning experience; and this in turn promotes the development of a passion for entrepreneurship through the process of behavioural integration. We also discover that this interplay between the identity and activity occurs deep in the microfoundation cognitive-structure of the students. With the reference to both issues and the location of the interplay, our general and broad research question that guides us to address the above research objective is: in what condition the students with their unique personal identities could respond more effectively and rigorously with the presented learning stimuli during the entrepreneurial learning activity, which could then result in the development of entrepreneurial passion.

\section{METHODOLOGY}

In light of this, we choose a narrative literature review approach with a goal to identify and propose a theoretical framework of what may be absent in the current EEP delivery setup. The narrative literature review approach is found to be a suitable approach to tackle the broader and more abstract research question (Baumeister \& Leary 1997), such as what this paper intends to do. While many significant studies have been carried out in the field of entrepreneurship in regard to the entrepreneurial learning process, entrepreneurship education and entrepreneurial passion (e.g. Politis 2005; Ardichvili, Cardozo \& Ray 2003; Neck \& Greene 2011; Winkel 2013; Cardon et al. 2009) as well as in the phenomenon of passion in everyday activities in the positive psychology strand (e.g. Klaukien \& Patzelt 2008; Philippe, Vallerand \& Lavigne 2009; Vallerand 2008), all these studies are found to differ from each other. The narrative literature review approach is suitable in bridging the link between these theories as it can offer a valuable theory-building technique, and it may also serve the hypothesis-generating functions.

Baumeister and Leary also propose that there are five main goals of narrative literature review approach that can also relate to this paper's objective, namely; (1) providing a context for describing, elaborating, and evaluating a new theory, (2) offering platform for theory evaluation, where the authors do not offer a new theoretical perspective but rather review the literature relevant to the validity of an existing theory (or often two or more competing theories), (3) giving opportunity to survey the state of knowledge on a particular topic by providing a useful overview and integration of a related area, (4) identifying the problem thoroughly by revealing problems, weaknesses, contradictions, or controversies in a particular area of investigation, and finally (5) providing a historical account of the development of the theory and research. Furthermore, there are several factors that cause this paper to choose a narrative literature review approach over the more constricted systematic literature review approach.

The objective of this paper is found to be aligned with the criteria outlined by Cook, Mulrow and Haynes (1997). The narrative literature review approach focuses on the broad research question that is sourced and selected from not usually specified, and potentially biased research materials (i.e. entrepreneurship learning process, entrepreneurship education, development of passion for an activity), while the evaluation emphasises on the variable itself, the synthesis is often qualitative and the inferences are sometimes evidence-based. Meanwhile, the systematic literature review approach is not selected because it is too narrow as it focuses upon the specific and tight research question, which comes from comprehensive sources and explicit search approach from criterion-based selection and is uniformly applied. Furthermore, the evaluation also involves rigorous critical evaluation and the synthesis is in quantitative form, while its inferences are usually evidence-based. In the next section, the narrative literature review is presented and this is followed by the proposed theoretical framework as the main finding of this paper.

\section{NARRATIVE LITERATURE REVIEW}

\section{ENTREPRENEURIAL LEARNING PROCESS}

In principle, entrepreneurial learning process (ELP) explicates the continuous process that facilitates the development of necessary knowledge for effective startups and management of new business ventures (Politis 2005: 401). ELP occurs when individuals' experience is transformed into entrepreneurial knowledge during the experiential (acquisition and assimilation) stage - where new information is cognitively accepted or rejected by the individual learner. Even though this transformation process is not straightforward, it involves factors such as outcomes of previous events, predominant logic/ reasoning, and career orientation (Politis 2005). Drawing from Experiential Learning Theory by Kolb (1984), Politis further argues that the acquisition and transformation of experience are central to the learning process that combines the individuals' existing knowledge, cognition, and experience.

Given the above understanding, we found that the integration between knowledge (existing and new) and the human cognitive system is therefore deemed to be crucial during ELP as both can directly impact individuals' experience. Shane and Venkataraman (2000) argue 
that individuals must possess both existing knowledge and cognitive properties as prerequisites to value the importance of the new information presented to them. Such knowledge is important in identifying new meansends relationships through the logic of causation and effectuation reasoning (Sarasvathy 2001). For instance, individuals who use effectuation prefer an experimental and iterative mode of transforming an experience to predict future events. Meanwhile, individuals who use causation prefer to utilise their pre-existing knowledge as the control source of cognitive judgement. Krueger (2009) postulates that acquiring entrepreneurial knowledge is not just a process of accumulating data but rather it is a form of organising and structuring the information content. Given that, clearly, the way of acquiring and transforming the information is very different from one person to another as they possess a different set of knowledge and cognitive properties. Therefore, by applying this situation to the ELP, there is a very huge possibility of output dissimilarities among the students when they are given a similar set of problems. This is again due to the different manners of how individuals combine the new and existing knowledge to produce new entrepreneurial knowledge, which also extends to the notion of how they respond to the learning stimuli presented to them and how they execute things after that.

From the above discussion, it is clearly shown that the combination of components of individuals, knowledge, information and cognitive system produce new entrepreneurial knowledge. Extensive research on this process has been carried out (e.g. Corbett 2005; Harrison \& Leitch 2005; Cope 2003). Accordingly, there are two major issues in regard to individuals' existing knowledge influencing the way individuals produce new entrepreneurial knowledge in ELP.

The first issue concerns with the types of existing knowledge that individuals have at their disposal, which could influence them during the ELP. Ardichvili et al. (2003) classify these existing knowledge stocks into four categories, namely: (1) special interest knowledge and general industry knowledge; (2) prior knowledge of markets; (3) prior knowledge of customer problems; and (4) prior knowledge of ways to serve markets. Ardichvili et al. further argue that individuals (depending on the context) may choose to combine or not to combine the knowledge stocks at their disposal while evaluating the new knowledge. Theoretically, in effective and ideal EEP setting, the students are required to choose and apply all four knowledge stocks during the ELP. However, given that everyone is unique, individuals will normally choose several combinations of knowledge stocks or in some cases, they may decide to choose just a solitary knowledge stock to respond to the new learning stimuli. This preference to choose the types of knowledge to be used usually resides in their dominant existing knowledge capacity, referred to as 'heuristic knowledge' (Busenitz \& Barney 1997; Baron 1998). It is also normally used more expansively in the execution of an entrepreneurial action via a cognitive mental process of preferred thinking style that is also known as 'heuristic thinking' (Mitchell et al. 2002; Baron \& Ward 2004). In ELP, heuristic thinking (HT) will act as the main 'thinking cap.' It tends to be used by the students as it subconsciously defines their dominant personal identity during the entrepreneurial learning activity.

In the meantime, the second issue of ELP relates to the condition that can promote effective ELP. It consists of (1) the level of depth of cognitive processing that individuals leverage on to process the new information (Mitchell et al. 2007; Krueger 2007) and, (2) on how individuals' dimensions can significantly affect the depth of the thinking while processing the new entrepreneurial experience (Baron 1998, 2004). Without the required level of cognitive ability (Baron 2004; Krueger 2007) to process the newly presented information, the instrumentality of individuals' perceived ability to make use of their existing knowledge may not be deeply felt. Therefore, causing them to be less affectionate to further commit to the learning process. Krueger $(2007,2009)$ argues that effective ELP should occur deep in the cognitive structure of individuals. This is because it enables the individuals to validate the external information more affectionately, and therefore makes better sense of the information; because after all, the cognitive processes is the one that shapes the representations of knowledge, which in turn affects future action (Corbett \& Hmieleski 2007). As such, the deeper the new information is being processed by the individuals, the more affection is being invested. This is because the more important the new information (learning stimuli) is to the individuals. In the next section, the nature of heuristic thinking of how it is used during the ELP is discussed.

\section{NATURE OF HEURISTIC THINKING}

Heuristic thinking (HT) is defined as the preferred thinking style used by individuals for the execution of an action during learning process (Mitchell et al. 2002; Baron \& Ward 2004).

Holcomb et al. (2009) classified the characteristics of different types and nature of heuristic into three categories, of namely; (1) availability, (2) representativeness, and (3) anchoring and adjustment. These characteristics are mainly responsible for explaining variations in the ELP. HT is responsible for orients of individuals to the information cues or content. Moreover, it allows individuals to produce new knowledge in which individuals rely upon to recognise and exploit any entrepreneurial opportunities. The successful application of HT can produce new behavioural patterns, judgmental structures, and generative mechanisms for action. HT can be highly adaptive and beneficial to the accumulation of knowledge because it can offer a great sense of familiarity with an action. Besides, the notion of HT is also consistent with personality literature where it posits that individuals have a unique set of inherent, stable, and enduring personality characteristics, in which 
incline them towards entrepreneurial activity (Greenberger \& Sexton 1988).

The combination of the application of HT with Postle's (1993) argument that emotion should be the foundation of all experiential learning and it needs to be emphasized. It would result in an 'affective' mode of learning that finds expression from doing (i.e., through immersion in the activity itself) as well as promoting emotions as determinants of entrepreneurial exploitation by using affect-as-information theory and the affective processing principle as conceptual bases (Welpe et al. 2012). This combination may, therefore, establish the strong linkage between HT and ELP. This is because HT can be seen as the dominant and preferred thinking style during ELP. For instance, during entrepreneurship learning activity, the students may mainly utilise their own HT to analyse and come up with the action based on the information they process from their encounter with the learning stimuli. In certain cases, due to the strong individuals' HT style, it may have a double-sword effect on the experience that they obtain in EEP. The failure to find a significant usage of HT with the learning activity may hinder the students from exploring more of the entrepreneurial opportunity nexus, and therefore lessen their passion towards entrepreneurship. In contrast, the learning activity that suits the HT of the students may yield a more engaging ELP session. This is because the students experience a profound meaning of how they can utilise their unique strength (HT) in entrepreneurship setting. This situation could lead to a successful behavioural integration process that represents a successful validation of personal identity and activity in ELP.

\section{ENTREPRENEURSHIP EDUCATION PROGRAMME DELIVERY}

Following Van Manen (1990, 1994) conceptualisation of the "lived experience," pedagogy is seen to be composed of teaching and learning elements. Pedagogy, according to Van Manen (1990) is the activity that is concerned with the activity of teaching, educating, or generally living (being there) with the children (students), which requires practical acting in concrete situations and relations. Meanwhile, in the entrepreneurship education literature, the entrepreneurship education pedagogy, according to Kirby $(2004,2006)$, pedagogy is related to the "what" and the "how" of entrepreneurship education. Pedagogy of entrepreneurship education operates with the intention of changing the way people are taught as well as what they learn (Jones \& Iredale 2010). This is because it is not subject-specific but can be introduced and applied across a wider curriculum (Iredale 2002).

Hindle (2007: 107) suggests that there are two broad areas of pedagogy in EEP delivery; namely: (1) teaching entrepreneurship and (2) teaching about entrepreneurship. The former refers to an act of embracing the vocational area of entrepreneurship, by applying the practical components of a highly applied area of knowledge similar to a medical doctor, or engineer, or lawyer and others. Meanwhile, the latter refers to an act of recognising entrepreneurship as a phenomenon, in which it regards the meta-aspects of entrepreneurship. Here, it concerns with the theory and the way entrepreneurship impacts other phenomena.

Accordingly, there is an array of issues that directly related to EEP delivery, namely: (1) the teaching approaches, (2) the qualification of EEP educators, (3) the diversity in the classroom, and (4) the method to record or assess the pedagogical impact of EEP.

EEP Teaching Approaches Mwasalwiba (2010) found that there are two dominant teaching approaches in EEP, namely; (1) traditional and (2) innovative (action-based). The former focuses upon the stand-and-deliver method of disseminating knowledge. It relates to entrepreneurship process of planning and prediction by using business plan and case studies. Scholars argue that this approach is very much a behaviourist approach, which is based on theory and didactic method. Reliance on dominant teaching methods such as lectures, cases, projects and entrepreneur presentations, may or may not be delivered in a manner that can stimulate entrepreneurial behaviour (Gibb 2007). Furthermore, Pittaway and Edwards (2012) argue that this approach still dominate whereby "teaching about entrepreneurship" pushes "teaching entrepreneurship" to the side-line. Recently, Piperopoulos and Dimov (2014) found that the teaching approach employed by the entrepreneurship educators, both theoretical and practical directly impact students' motivational frame of either through promotion or prevention form. On the other hand, in response to the criticisms of the traditional ones, scholars proposed the latter. This approach is more experiential, in which entrepreneurship educators shift their role from 'the sage on stage' to 'a guide on the side' (Hannon 2005). This is done by helping the students to understand, develop, and practice the skills and techniques needed for productive entrepreneurship through starting businesses as part of coursework, playing entrepreneurship's games and simulations, design-based learning which involved observation, fieldwork and analysis of venture opportunities and finally a reflective practice (Neck \& Greene 2011).

EEP Educators Qualification By being labelled as an entrepreneurship educator, that person is considered as the 'specialist teacher' of entrepreneurship education. However, this is unlikely the case, Bennett (2006) found that entrepreneurship educators do not have the consensus on how entrepreneurship should be taught. Bennett found that this is because the entrepreneurship educators believed that their own definition of entrepreneurship influences their ability to transfer entrepreneurship knowledge to the students. As such, entrepreneurship educators are perplexed between the aims and practices in EEP (SeikkulaLeino et al. 2010). Based on the systematic review of entrepreneurship education, Pittaway and Cope (2007a) found that it is unclear whether EEP affects graduate 
entrepreneurship. Furthermore, the EEP's positive and intended impact from the lessons learned through the educators towards graduates' initial experience in the marketplace remains inconclusive. Perhaps, one of the issues appeared to nullify the impact of EEP delivery is the subscription of conventional business style work by entrepreneurship educators to expose students to entrepreneurship knowledge. Gibb $(2007,2005)$ argues that this is likely the case in most EEP's. The educators focus on business and business-concept, and the context is dominantly that of business with corporate business culture. This subsequently narrows the teaching method and over-focused upon business case study. As a result, Matlay (2008) found that graduates' need for EEP do not match the actual outcomes, i.e. in terms of entrepreneurial skills, knowledge, and attitudes

Diversity in EEP 'One size fits all' teaching design is incapable in dealing with the variations that exist in the classroom. After all, in the setting of EEP classroom, the students learn at different rates, have different levels and types of motivations, start with different bases of knowledge and experience, and have access to different resource networks. On the other hand, entrepreneurship educators have different specialities, different levels of capability, and different resource networks, and this standard teaching design cannot be a generalised optimal process considering entrepreneurship process is individual-level focused process (Vanevenhoven 2013). Due to multiple attributes, qualities, skills, and knowledge required for the different roles of entrepreneurship, according to Anderson and Jack (2008), entrepreneurship educator needs extra ability, capacity and flexibility to produce content that combines and demonstrates the creative talents of the artist, the skills and ability of artisan, yet includes the applied knowledge of the technician with know-what of a professional. This is because education process has to be seen from the social reality perspective, which emphasizes on the expression of a relationship and individuals are relational beings that are constantly becoming and emerging in relation to the context in which entrepreneurial activities are going to be constructed (Fletcher 2007).

Measuring Tool to Record and Assess the Impact of EEP Present a way to account the impact of EEP that normally starts and ends with entrepreneurial intention. Several studies have demonstrated that a good EEP includes the perception of whether the content received by the students from the entrepreneurship educator can increase individuals' entrepreneurial self-efficacy (Bae et al. 2014; Liñán et al. 2011; Rauch \& Hulsink 2014). However, these studies seem to be lacking in the nuanced detail of the way of how students are actually experiencing ELP (e.g. how EEP triggers the change of behaviour deep in the cognitive system of individuals). The entrepreneurial intention generated from EEP can be regarded as merely a signal or entrepreneurial aptitude for students to sort what they really want to do (Graevenitz Harhoff \& Weber 2010) and some other constructs such as entrepreneurial passion may translate that signal into real entrepreneurial action.

At this juncture, we established the fact that first, there is a strong understanding that during the ELP, individuals have greater tendency to utilise their HT while processing the new information that occurs deep in the individuals' microfoundation. By successfully finding the significant application of HT with the learning activity, the students will explore more of the entrepreneurial opportunity nexus. Therefore, increases their affection to learn more about entrepreneurship as they have found ways to utilise their unique strength (HT) effectively. Secondly, we established the case that EEP delivery is strongly linked to the students' pedagogical experience. Therefore, there is a need to engage the students with the right pedagogical delivery in the EEP, which allows the students to feel the importance of entrepreneurship to them and concurrently develop a sense of affection that they are directly connected to entrepreneurship. They must have a strong belief that there is a mutual benefit between entrepreneurship and them. Entrepreneurship must be seen as a proxy that serves their ongoing personal well-being quest, and that their social circle can also benefit from their future entrepreneurial actions due to their HT application. There must be the idea of reciprocating action relationship between the three cornerstones (students, educators, and pedagogy) during the ELP through sound EEP delivery. In the next section, we will discuss how entrepreneurial passion is developed within a situated setting of EEP.

\section{ENTREPRENEURIAL PASSION DEVELOPMENT IN EEP}

Thus far, the paper proposes that EEP pedagogical experience provides a platform for students to process the information and allows 'experienced' individuals with knowledge to foresee and take advantage of entrepreneurial opportunities through the successful application of HT. This is because some individuals may find that such familiarity is beneficial to opportunity recognition (including problem-solving) especially if it occurs in a familiar territory. For instance, individuals with experience in troubleshooting the problem in their specialisation have more chances of organizing links between otherwise independent events in memory, speeding the retrieval of knowledge and enhancing the accuracy of judgments when they consider similar opportunities/problems in the future and create a sense of affection for the future decision. This condition is in line with Holcomb et al.'s (2009) argument that learning facilitates this cognitive process by increasing the saliency of an event class. Specifically, knowledge structures that formed with repetition, whether through direct experience or observation and consist similar event instances, increase the likelihood that people will perceive the events as being more probable and frequent.

Individuals' familiarity with effective ELP increases the positive relationship between ease of recall for learned events of a given class, whether experienced or observed, 
and the perceived future probability of similar events; thus developing some affection to it. After all, individual learning is a dialectical process that comprises both access to new knowledge and the ability to assimilate such new knowledge into current knowledge sets (Baum, Bird \& Singh 2011; Kolb 1984). This notion is consistent with the ability of individuals to fill the information gap and find asymmetries in the knowledge they learned (Shane 2003; Corbett 2007). Pittaway and Cope (2007b) validate that it is possible to simulate aspects of entrepreneurial learning, such as emotional exposure and situated learning. Therefore, a sense of affection in the form of entrepreneurial passion may then develop when HT interplays with the profound pedagogical experience that recognises individual's unique strength within their own social circle.

Nevertheless, existing work on the development of passion for an activity emphasizes on the importance of personal appraisal that encapsulates the "in situ" process prior to any engagement toward a certain activity is established (e.g. Amabile 1996, 2012; Cardon et al. 2009; Zigarmi et al. 2009; Goss 2008; Baron 2008; Vallerand et al. 2003). This intrinsic appraisal involves ongoing evaluation of personal experiences, which begins from the initial contact with the activity up to the deciding point of whether to prolong the commitment or otherwise. It encapsulates the role of the person-environment dialectic in the selection of self-growth activities. This personal evaluation of experience that underpins the depth of connection between the activity and identity results in behavioural integration (Vallerand et al. 2003; Ryan \& Deci 2000), and is seen as crucial to the development of a passion for something. Therefore, most existing research into how passion occurs in a particular context emphasizes on the link between activities and existing predispositions (Amabile 1996, 2012; Zigarmi et al. 2009). Work on entrepreneurial passion has also focused specifically on the link between the relevance and relatedness of the entrepreneurial activity and the unique entrepreneurial identity of individuals (see: Goss 2008; Cardon et al. 2009; Murnieks, Mosakowski \& Cardon 2014). Vallerand's $(2008,2015)$ theoretical framework on the temporal development of passion in an activity suggests that the personal appraisal process would include: (1) activity selection, (2) activity valuation, and (3) the type of internalisation of the activity representation in one's identity, which may be represented by the ELP in the EEP context.

First, for passion to be developed, a psychological recognition that certain activities in the ELP are preferred than others is needed. It represents the role of psychological needs in activity preference, which specifies people's choice, i.e. from trying out a variety of activities to selecting a specific activity and becoming passionate about it (Vallerand 2015). Generally, people select the specific activity over the rest because they foresee opportunities that they can exploit, through the significant match with their own existing predispositions, or domain-related skills or knowledge (Amabile 1996, 2012; Forest et al. 2010; Goss 2010). Presumably, students have different motives of why they enrol in entrepreneurship-related programmes. By joining EEP, students either want to strengthen their existing entrepreneurial skills and knowledge, may want to discover new entrepreneurial skills and knowledge beyond, or perhaps want to equip themselves with relevant entrepreneurial skills and knowledge before making career transition by starting up their new ventures. This first process, therefore, should be viewed as the 'main entrance' of the development of passion, in which passion is determined prior to the experience of the activity. As such, individuals are seen to be as psychologically prepared to experience the EEP in the way they perceived the activity in the ELP may have a significant match with their existing identity that is akin to the identity process of being.

Second, a subjective evaluation of activities in the ELP occurred, whereby the intensity or feelings associated with tasks are evaluated. In this process, the role of the social environment in the satisfaction of psychological needs takes place (Vallerand 2015). The environment will consequently determine, at least in part, the extent to which personal psychological needs will be satisfied. In particular, by participating actively in the activity, people are opening up themselves to the experience and then identify themselves with the activity, or not, by questioning whether the activity in the ELP can: (1) satisfy their basic need for autonomy, competence and relatedness (Vallerand et al. 2003) and (2) match with their domainrelevant skills (Amabile 2012; Amabile 1996). When ELP activities greatly resonate with a person's sense of self, the person will begin to think of themselves regarding the activity (Aron, Aron \& Smollan 1992). Taking this context into entrepreneurship literature, Murnieks et al. (2014) suggest that a certain degree of mental negotiation occurs when a person attempts to internalise the meaning of the activity with the entrepreneurial role that they required to perform. A cognitive process is worked through where people reflect upon and think about whether or not the activities are important to the self-concept of who they are, who they want to be and what they need to do to legitimise that role (Stryker \& Serpe 1994). Since this cognitive process allows individuals to practice their freedom to choose which activities or identities truly define them, the process is deemed autonomous or self-directed. Therefore, it can be suggested that during this process, individuals psychologically opened up themselves to the experience that they may or may not encounter during the provision of EEP and perceived that the activity during the ELP is about the identity process of becoming.

The final process in the development of passion results in behavioural integration of activity of EEP to a person's existing identity. When the activity is felt to be central to individual identity, then strong motivational forces can arise from such feelings; which can positively (or negatively) influence subsequent task performance. 
This final evaluation underpins the identity process of being and becoming (Van Manen 1990). The process involves self-evaluation of four basic motives: selfassessment, self-enhancement, self-verification, and self-improvement (Vallerand \& Rip 2006). In the search for usable information, the self will focus on information triggered by the situation or individuals' personality. The sources of information used in the process are in line with the concept of coming up with identity information, which includes: social environment, observation of his or her own behaviour, and personal experiences and recollections (Vallerand 2015: 56).

In a nutshell, the experience obtained from EEP as a whole or part of ELP activities may provide a support to the notion of being and /or becoming passionate for entrepreneurship as they undergo first-hand experience under the pedagogy of entrepreneurship during EEP. Fredricks, Alfeld and Eccles (2010) suggest that the most likely consequences of the emergent of passion for certain activities are (1) the person wanting to do the activity all the time and devoting significant time and energy, (2) getting completely involved in the activity and experiencing flow, and (3) getting emotional release from the activity and seeing one's identity in terms of the activity and these 'benefits' of passion are linked to performance improvements.

\section{FINDINGS AND DISCUSSION}

The summary of the narrative literature reviews as shown in Table 1 brought the paper to the proposition of three cornerstones of entrepreneurial passion development in EEP, in which act-as the theoretical framework that may be missing in the current EEP delivery. The review shows that it is important to examine the deep cognitive structure of individuals that richly consist of HT. In order to transform that entrepreneurial knowledge into action, the connection of individuals' unique HT that embodies the unique personal identity needs to be further established via suitable entrepreneurial learning orientation. This is done through the offering of a profound pedagogical experience. Secondly, ELP needs to be supported with suitable contextual elements to give the right amount of space and push in the interaction between HT and entrepreneurship. Thirdly, the content and context of entrepreneurship education delivery are the direct elements that can influence the development of entrepreneurial passion. Both elements can interplay with the deep cognitive structure of individuals of perceiving the feasibility of utilising their HT in entrepreneurial learning activity, represented by the input of unique HT at their disposal. Therefore, this paper proposes the entrepreneurial passion development in EEP theoretical framework as shown in Figure 1.

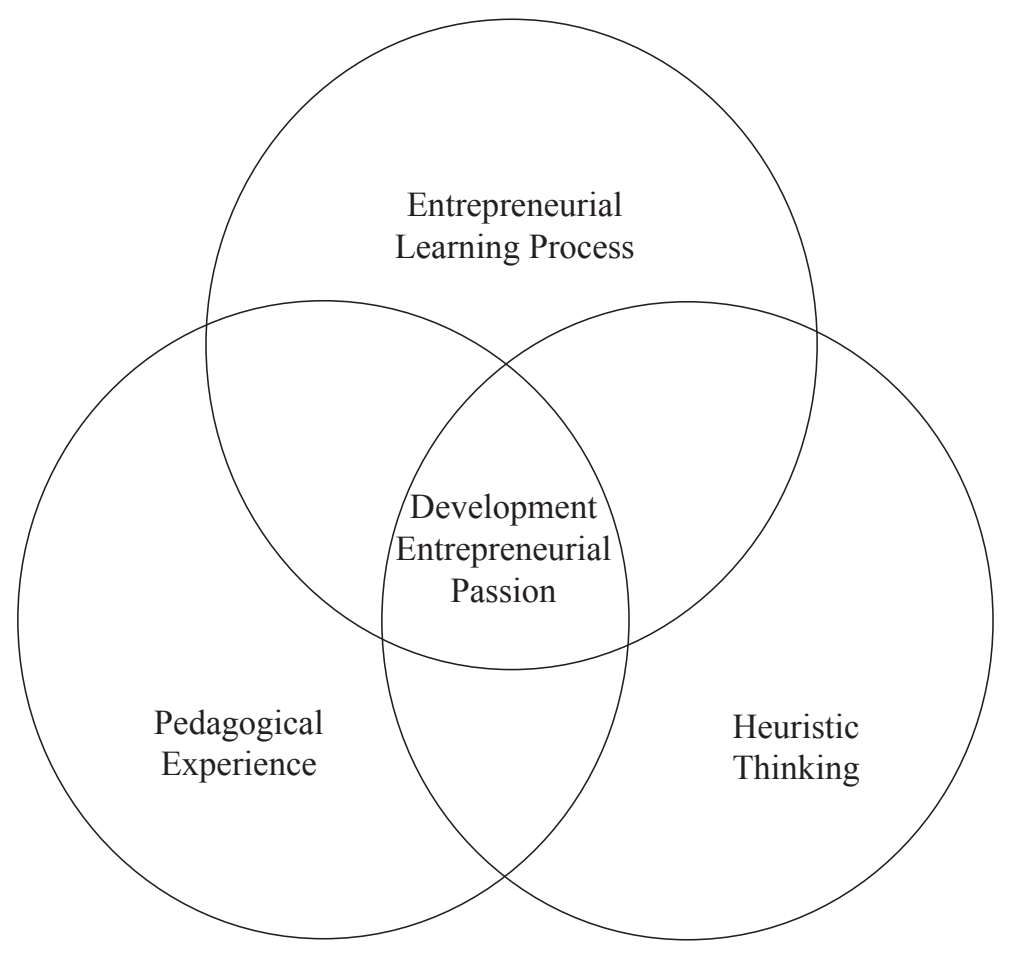

FIGURE 1. Theoretical framework of the development of entrepreneurial passion in entrepreneurship education programme 
TABLE 1. Summary of narrative literature review and synthesis

\begin{tabular}{|c|c|c|c|}
\hline Theme & & Literature Summary & \\
\hline $\begin{array}{l}\text { Entrepreneurial Learning } \\
\text { Process (ELP) }\end{array}$ & Politis (2005) & $\begin{array}{l}\text { Shane \& Venkataraman } \\
(2000)\end{array}$ & Krueger (2009) \\
\hline
\end{tabular}

ELP provides a suitable platform for the students to apply their unique HT while recognising the opportunity nexus.

The successful application of students' HT, represented by the feeling of satisfaction appreciated in entrepreneurship the experiential (acquisition and activity, will strengthen their assimilation) stage - where new belief in the self-relevance of information is cognitively accepted entrepreneurship to them.

ELP is a continuous process that facilitates the development of necessary knowledge for being effective in starting up and managing new business ventures.

The process occurs when individuals' experience is transformed to become knowing that their HT is being entrepreneurial knowledge during

The acquisition and transformation of experience are central to the learning process that combines the integration of individuals' previous knowledge, cognition, and experience.

\begin{tabular}{llll}
\hline $\begin{array}{l}\text { Cognitive Processing of } \\
\text { Existing Knowledge }\end{array}$ & Ardichvili et al. (2003) & Krueger (2007) & $\begin{array}{l}\text { Baum et al. (2011) } \\
\text { Kolb (1984) }\end{array}$ \\
\hline It is crucial that the EEP & There are four types of prior & The process should occur & The cognitive process is a
\end{tabular}
delivery is able to provide the knowledge that will be transformed deep in the cognitive structure dialectical process that types of activities that allow the into the entrepreneurial knowledge of individuals; hence enabling comprises both access to new students to apply their existing namely:

knowledge and try to make sense of the knowledge in the context of entrepreneurship.
Individuals must possess both The transformation of new prior knowledge and the necessary to value such knowledge in order to identify new means-ends relationships as knowledge forms the basis of individuals cognitive reasoning through the logic of causation and effectuation. cognitive properties knowledge to entrepreneurial knowledge is not just an accumulation of data; knowledge requires both information content and the structure by which we organize it. the individuals to validate the knowledge and the ability to external information and assimilate such new making sense of it in the context of entrepreneurship. knowledge sets knowledge into current
(1) special interest knowledge and general industry knowledge;

(2) prior knowledge of markets;

(3) prior knowledge of customer problems; and

(4) prior knowledge of ways to serve markets.
Mitchell et al. (2002)

Baron \& Ward (2004)

Thinking in Entrepreneuria

Learning Process

There is a great tendency that individuals will prefer to utilise their HT in dealing with entrepreneurial learning stimuli, therefore, any activity that facilitates the use of HT will allow better personal evaluation of the activity with the students' current personal identity.
Heuristic thinking is defined as the preferred thinking style used by individuals for execution of an action during the learning process

Holcomb et al. (2009)

Greenberger \& Sexton (1988)

There are three different types Heuristic thinking is of heuristic thinking namely: consistent with the

[1] availability,

[2] representativeness, and which posits that individuals

[3] anchoring and adjustment have a unique set of inherent,

Heuristic thinking is stable, and enduring personality characteristics responsible first, to orient that incline them toward individuals to the information entrepreneurial activity. cues or content and, secondly, to allow individual's action to produce new knowledge in which individuals rely to recognise and exploit opportunities. 
Heuristic thinking can be highly adaptive and beneficial to accumulation of knowledge because it can offer a strong feeling of familiarity with an action.

\begin{tabular}{l} 
Pedagogical Experience \\
\hline It is a pure and direct \\
experience that the students \\
will undergo during the \\
entrepreneurial learning \\
process.
\end{tabular}

EEP sets the platform for the interplay between the pedagogical experience and the application of HT in entrepreneurial learning activity.

Jones \& Iredale (2010)
Iredale (2002)

\section{Pedagogy of entrepreneurship} education operates with the intention of changing the way people are taught as well as what they learn as it is not subject specific but can be introduced and applied across wider curriculum.
Hindle (2007)

Two broad areas of pedagogy in the EEP delivery namely:

(1) teaching entrepreneurship - an act of embracing the vocational area of entrepreneurship, by applying highly applied area of knowledge similar to a medical doctor, or engineer, or lawyer and others and (2) teaching about entrepreneurship - an act of recognising entrepreneurship as a phenomenon, which considers the meta-aspects of entrepreneurship; and is concerned with the theory and the way entrepreneurship impacts other phenomena the practical components of a

Piperopoulos \& Dimov (2014) Anderson \& Jack (2008)

The teaching approach employed by the entrepreneurship educators, both theoretical and practical directly impact the students' motivational frame of either through promotion or prevention form.

Entrepreneurship educator needs extra ability, capacity and flexibility to produce content that combines and demonstrates the creative talents of the artist, the skills talents of the artist, the skills includes the applied knowledge of the technician with know-what of a professional

\begin{tabular}{llll}
\hline Development of & Amabile (1996, 2012) & Vallerand (2008, 2015) & Vallerand and Rip (2006) \\
Entrepreneurial Passion & Cardon et al. (2009) & \\
& Zigarmi et al. (2009) & \\
& Goss (2008) & \\
& Baron (2008) & \\
\hline
\end{tabular}

The process revolves deep in It involves the personal appraisal The temporal development of The behavioural integration the microfoundation of the that encapsulates the "in situ" students - on-going evaluation process prior to any engagement - iterative process - when toward a certain activity is needed passion in an activity involves process involves the selfthe personal appraisal process evaluation of four basic that includes: motives: everything is favourable, entrepreneurial passion is developed.
(1) activity selection,
(2) activity valuation, and
(3) the type of internalization
of the activity representation
in one's identity
(1) self-assessment,
(2) self-enhancement,
(3) self-verification, and
(4) self-improvement .

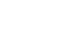


The process of developing entrepreneurial passion requires the familiarity with an action when it interacts with the learning activity. Individuals' familiarity with the objective of activities of ELP increases the positive relationship of ease of recall for learned events, let it be either experienced or observed. Moreover, the perceived future probability of similar events, will therefore, develop some sort of affection to it. Individual learning is a dialectical process that comprises both access to new knowledge and the ability to assimilate such new knowledge into current knowledge sets (Baum et al. 2011; Kolb 1984). This notion is consistent with the ability of individuals to fill the information gap and find asymmetries in the knowledge they learned (Shane 2003; Corbett 2007). Pittaway and Cope (2007b), validate that it is possible to simulate aspects of entrepreneurial learning, such as emotional exposure and situated learning. Therefore, a sense of affection or entrepreneurial passion may develop when HT interplays with the pedagogical experience that allows the recognition of the individuals' signature strength within their social circle.

Altogether, through the narrative literature approach, we found that the development of entrepreneurial passion while undergoing the experience of entrepreneurial learning is possibly the missing piece in the literature, which is very influential in promoting the students' interest to learn entrepreneurship and consequently become more entrepreneurially oriented. We offer refreshing insights about the significance of HT in the ELP as well as its interplay with the pedagogical experience, which can promote the sense of identification to the entrepreneurship activity and deep sense of belonging to entrepreneurship. We propose that by recognising this crucial interplay in ELP, the students' unique heuristic thinking will eventually be appreciated. This will then trigger a more intense reaction and reflection through the profound recognition of individuals' worthiness in the social circle and deep sense of affection to entrepreneurship; and consequently allows the entrepreneurial passion to be experienced by the students.

\section{CONCLUSION}

In conclusion, this paper discusses in detail the way to improve the current EEP delivery setup. This paper is guided by the research question of: in what condition will the students, with their unique personal identities, could respond more effectively and rigorously with the presented learning stimuli during the entrepreneurial learning activity that could then result in the development of an entrepreneurial passion. We propose that the missing linkage consists of three cornerstones that facilitate the development of entrepreneurial passion in the EEP. Those cornerstones are entrepreneurial learning process, pedagogical experience and heuristic thinking. ELP serves as the platform for students to process new information by using their existing knowledge stock. We offer refreshing insights into the importance of HT, which subconsciously embodies the students' personal identity, and its interplay with the pedagogical experience during the ELP; in which is crucial in promoting a strong sense of identification with entrepreneurial-related activity and a strong affinity towards entrepreneurship. By recognising this missing element and linkage, the students will feel that their unique signature strength is being more appreciated in the social circle; thus triggering a more intense reaction towards the learning stimuli. This is because they feel the profound recognition of their worthiness in the social circle as well as the development of a stronger belief about the mutual benefit between entrepreneurship and their ongoing personal well-being life quest. This will consequently allow their entrepreneurial passion to be further developed.

\section{REFERENCES}

Amabile, T.M. 1996. Creativity in Context. Oxford: Westview Press.

Amabile, T. M. 2012. Componential Theory of Creativity: Harvard Business School.

Anderson, A.R. \& Jack, S.L. 2008. Role typologies for enterprising education: The professional artisan? Journal of Small Business and Enterprise Development 15(2): 259-273.

Ardichvili, A., Cardozo, R. \& Ray, S. 2003. A theory of entrepreneurial opportunity identification and development. Journal of Business Venturing 18(1): 105-123.

Aron, A., Aron, E.N. \& Smollan, D. 1992. Inclusion of other in the self scale and the structure of interpersonal closeness. Journal of Personality and Social Psychology 63(4): 596612.

Bae, T.J., Qian, S., Miao, C. \& Fiet, J.O. 2014. The relationship between entrepreneurship education and entrepreneurial intentions: A meta-analytic review. Entrepreneurship: Theory \& Practice 38(2): 217-254.

Baron, R. 2008. The role of affect in the entrepreneurial process. Academy of Management Review 33: 328-340.

Baron, R.A. 1998. Cognitive mechanisms in entrepreneurship: Why and when enterpreneurs think differently than other people. Journal of Business Venturing 13(4): 275-294.

Baron, R.A. 2004. The cognitive perspective: a valuable tool for answering entrepreneurship's basic "why" questions. Journal of Business Venturing 19(2): 221-239.

Baron, R.A. \& Ward, T.B. 2004. Expanding entrepreneurial cognition's toolbox: Potential contributions from the field of cognitive science. Entrepreneurship Theory and Practice 28(6): 553-573.

Baum, J.R., Bird, B.J. \& Singh, S. 2011. The practical intelligence of entrepreneurs: Antecedents and a link with new venture growth. Personnel Psychology 64(2): 397-425.

Baumeister, R.F. \& Leary, M.R. 1997. Writing narrative literature reviews. Review of General Psychology 1(3): 311-320.

Bennett, R. 2006. Business lecturers' perceptions of the nature of entrepreneurship. International Journal of Entrepreneurial Behavior and Research 12: 165-188.

Brewer, M.B. 1991. The social self: On being the same and different at the same time. Personality and Social Psychology Bulletin 17(5): 475-482. 
Busenitz, L.W. \& Barney, J.B. 1997. Differences between entrepreneurs and managers in large organizations: Biases and heuristics in strategic decision-making. Journal of Business Venturing 12(1): 9-30.

Cardon, M.S., Wincent, J., Singh, J. \& Drnovsek, M. 2009. The nature and experience of entrepreneurial passion. Academy of Management Review 34(3): 511-532.

Cook, D.., Mulrow, C.D. \& Haynes, R.B. 1997. Systematic reviews: Synthesis of best evidence for clinical decisions. Annals of Internal Medicine 126(5): 376-380.

Cope, J. 2003. Entrepreneurial learning and critical reflection: Discontinuous events as triggers for 'higher-level' learning. Management Learning 34(4): 429-450.

Cope, J. 2005. Toward a dynamic learning perspective of entrepreneurship. Entrepreneurship Theory and Practice 29(4): 373-397.

Corbett, A.C. 2005. Experiential learning within the process of opportunity identification and exploitation Entrepreneurship: Theory \& Practice 29(4): 473-491.

Corbett, A.C. 2007. Learning asymmetries and the discovery of entrepreneurial opportunities. Journal of Business Venturing 22(1): 97-118.

Corbett, A.C. \& Hmieleski, K.M. 2007. The conflicting cognitions of corporate entrepreneurs. Entrepreneurship Theory and Practice 31(1): 103-121.

Donnellon, A., Ollila, S. \& Middleton, K.W. 2014. Constructing entrepreneurial identity in entrepreneurship education. The International Journal of Management Education 12(3): 490-499.

Duval-Couetil, N. 2013. Assessing the impact of entrepreneurship education programs: Challenges and approaches. Journal of Small Business Management 51(3): 394-409.

Eckhardt, J.T. \& Shane, S.A. 2013. Response to the commentaries: The Individual-Opportunity (IO) Nexus integrates objective and subjective aspects of entrepreneurship. Academy of Management Review 38(1): 160-163.

Fayolle, A. 2013. Personal views on the future of entrepreneurship education. Entrepreneurship \& Regional Development 25(7-8): 692-701.

Fayolle, A. \& Gailly, B. 2008. From craft to science: Teaching models and learning processes in entrepreneurship education. Journal of European Industrial Training 32(7): 569-593.

Fletcher, D. 2007. Social constructionist thinking: Some implications for entrepreneurship research and education. In Handbook of Research in Entrepreneurship Education (Vol. 1), edited by A. Fayolle. Massachuchetts, USA: Edgar Edwards Publishing Limited.

Forest, J., Mageau, G.A., Crevier-Braud, L., Bergeron, É., Dubreuil, P. \& Lavigne, G.L. 2012. Harmonious passion as an explanation of the relation between signature strengths' use and well-being at work: Test of an intervention program. Human Relations 65(9): 1233-1252.

Fredricks, J.A., Alfeld, C. \& Eccles, J. 2010. Developing and fostering passion in academic and nonacademic domains. Gifted Child Quarterly 54(1): 18-30.

Garud, R. \& Giuliani, A.P. 2013. A narrative perspective on entrepreneurial opportunities. Academy of Management Review 38(1): 157-160.

Gibb, A. 2005. Towards the entrepreneurial university: Entrepreneurship education as a lever for change. National Council for Graduate Entrepreneurship. Available at www. ncge.org.uk.
Gibb, A. 2007. Creating the entrepreneurial university worldwide: Do we need a wholly different model of entrepreneurship. In Handbook of Research in Entrepreneurship Education: A General Perspective, edited by A. Fayolle. Cheltenham, UK: Edward Elgar Publishing.

Goss, D. 2008. Enterprise ritual: A theory of entrepreneurial emotion and exchange. British Journal of Management 19(2): 120-137.

Goss, D. 2010. Putting emotion at the heart of agency: A relational perspective on entrepreneurial action. Research on Emotions in Organizations 6: 63-84.

Graevenitz, G.v., Harhoff, D. \& Weber, R. 2010. The effects of entrepreneurship education. Journal of Economic Behavior \& Organization 76(1): 90-112.

Greenberger, D.B. \& Sexton, D.L. 1988. An interactive model of new venture initiation. Journal of Small Business Management 26(3): 1-7.

Hannon, P.D. 2005. Philosophies of enterprise and entrepreneurship education and challenges for higher education in the UK. The International Journal of Entrepreneurship and Innovation 6(2): 105-114.

Harrison, R.T. \& Leitch, C. M. 2005. Entrepreneurial learning: Researching the interface between learning and the entrepreneurial context. Entrepreneurship Theory and Practice 29(4): 351-371.

Hindle, K. 2007. Teaching Entrepreneurship at University: From the Wrong Building to the Right Philosophy. Cheltenham, England: Edward Elgar Publishing.

Holcomb, T.R., Ireland, R.D., Holmes Jr, R.M. \& Hitt, M.A. 2009. Architecture of entrepreneurial learning: Exploring the link among heuristics, knowledge, and action. Entrepreneurship Theory and Practice 33(1): 167-192.

Jones, B. \& Iredale, N. 2010. Enterprise education as pedagogy. Education + Training 52(1): 7-19.

Kirby, D. 2006. Entrepreneurship education: Can business schools meet the challenge? In International Entrepreneurship Education: Issues and Newness, edited by A. Fayolle \& H. Klandt. Cheltenham: Edward Elgar.

Klaukien, A. \& Patzelt, H. 2008. Entrepreneurial passion and its effect on decision making (summary). Frontiers of Entrepreneurship Research 28(6): 9.

Kolb, D.A. 1984. Experiential Learning: Experience as the Source of Learning and Development. Prentice: Hall Englewood Cliffs, NJ.

Krueger, N.F. 2007. What lies beneath? The experiential essence of entrepreneurial thinking. Entrepreneurship Theory and Practice 31(1): 123-138.

Krueger, N.F. 2009. The microfoundations of entrepreneurial learning and... education: the experiential essence of entrepreneurial cognition. In Handbook of University-Wide Entrepreneurship Education, edited by G. Page West III, E.J. Gatewood \&K.G. Shaver, 35-59. Cheltenham: Edward Elgar.

Liñán, F., Rodríguez-Cohard, J. \& Rueda-Cantuche, J. 2011. Factors affecting entrepreneurial intention levels: A role for education. International Entrepreneurship and Management Journal 7(2): 195-218.

Martin, B.C., McNally, J.J. \& Kay, M.J. 2013. Examining the formation of human capital in entrepreneurship: A metaanalysis of entrepreneurship education outcomes. Journal of Business Venturing 28(2): 211-224.

Matlay, H. 2008. The impact of entrepreneurship education on entrepreneurial outcomes. Journal of Small Business and Enterprise Development 15(2): 382-396. 
Meyer, G.D. 2011. The reinvention of academic entrepreneurship Journal of Small Business Management 49(1): 1-8.

Mitchell, R.K., Busenitz, L., Lant, T., McDougall, P.P., Morse, E.A. \& Smith, J.B. 2002. Toward a theory of entrepreneurial cognition: Rethinking the people side of entrepreneurship research. Entrepreneurship Theory and Practice 27(2): 93-104.

Mitchell, R.K., Busenitz, L.W., Bird, B., Marie Gaglio, C., McMullen, J.S., Morse, E.A. \& Smith, J.B. 2007. The central question in entrepreneurial cognition research 2007. Entrepreneurship Theory and Practice 31(1): 1-27.

Murnieks, C.Y., Mosakowski, E. \& Cardon, M.S. 2012. Pathways of passion: Identity centrality, passion, and behavior among entrepreneurs. Journal of Management 28(3): 373-396

Mwasalwiba, E.S. 2010. Entrepreneurship education: A review of its objectives, teaching methods, and impact indicators. Education + Training 52(1): 20-47.

Neck, H.M. \& Greene, P.G. 2011. Entrepreneurship education: Known worlds and new frontiers. Journal of Small Business Management 49(1): 55-70.

Ollila, S. \& Middleton, K.W. 2013. Exploring entrepreneurial identity construction: the case of an action-based entrepreneurship education. Paper presented at the Nordic Academy of Management (NFF), August 21-23, Reykjavik Iceland

Ollila, S., Middleton, K.W. \& Donnellon, A. 2012. Entrepreneurial Identity Construction-what does existing literature tell us? Paper presented at the Institute for Small Business and Entrepreneurship Annual Conference, Dublin Ireland.

Philippe, F.L., Vallerand, R.J. \& Lavigne, G.L. 2009. Passion does make a difference in people's lives: A look at wellbeing in passionate and non-passionate individuals. Applied Psychology: Health and Well-Being 1(1): 3-22.

Piperopoulos, P. \& Dimov, D. 2014. Burst bubbles or build steam? Entrepreneurship education, entrepreneurial selfefficacy, and entrepreneurial intentions. Journal of Small Business Management 53(4): 970-985

Pittaway, L. \& Cope, J. 2007a. Entrepreneurship education: A systematic review of the evidence. International Small Business Journal 25: 479-510.

Pittaway, L. \& Cope, J. 2007b. Simulating entrepreneurial learning integrating experiential and collaborative approaches to learning. Management Learning 38(2): 211-233.

Pittaway, L. \& Edwards, C. 2012. Assessment: examining practice in entrepreneurship education. Education + Training 54(8/9): 778-800.

Pittaway, L.A., Gazzard, J., Shore, A. \& Williamson, T. 2015. Student clubs: Experiences in entrepreneurial learning. Entrepreneurship \& Regional Development 27(3-4): 127 153.

Politis, D. 2005. The process of entrepreneurial learning: A conceptual framework. Entrepreneurship Theory and Practice 29(4): 399-424.

Postle, D. 1993. Putting the heart back into learning. In Using Experience for Learning, edited by D. Boud, R. Cohen, \& D. Walker, 33-45. Buckingham: SRHE \& Open University Press.

Rae, D. 2004. Entrepreneurial learning: A practical model from the creative industries. Education + Training 46(8/9): 492-500.

Rauch,A. \& Hulsink, W. 2014. Putting entrepreneurship education where the intention to act lies: An investigation into the impact of entrepreneurship education on entrepreneurial behavior. Academy of Management Learning \& Education 14(2): 187-204.

Richardson, I. \& Hynes, B. 2008. Entrepreneurship education: Towards an industry sector approach. Education + Training 50(3): 188-198.

Rideout, E.C. \& Gray, D.O. 2013. Does entrepreneurship education really work? A review and methodological critique of the empirical literature on the effects of university-based entrepreneurship education. Journal of Small Business Management 51(3): 329-351.

Ryan, R.M. \& Deci, E.L. 2000. Intrinsic and extrinsic motivations: Classic definitions and new directions. Contemporary Educational Psychology 25(1): 54-67.

Sarasvathy, S.D. 2001. Causation and effectuation: Toward a theoretical shift from economic inevitability to entrepreneurial contingency. The Academy of Management Review 26(2): 243-263.

Seikkula-Leino, J., Ruskovaara, E., Ikavalko, M., Mattila, J. \& Rytkola, T. 2010. Promoting entrepreneurship education: The role of the teacher? Education + Training 52(2): 117-127.

Shane, S. 2003. A General Theory of Entrepreneurship: The Inidividual-Opportunity Nexus. Northampton, MA: Edward Edgar Publishing Inc.

Shane, S. 2012. Reflections on the 2010 Amr decade award: Delivering on the promise of entrepreneurship as a field of research. Academy of Management Review 37(1): 10-20.

Shane, S. \& Venkataraman, S. 2000. The promise of entrepreneurship as a field of research. Academy of Management Review 25(1): 217-226.

Stryker, S. \& Serpe, R.T. 1994. Identity salience and psychological centrality: Equivalent, overlapping, or complementary concepts? Social Psychology Quarterly 57: 16-35.

Unger, J.M., Rauch, A., Frese, M. \& Rosenbusch, N. 2011. Human capital and entrepreneurial success: A metaanalytical review. Journal of Business Venturing 26(3): 341-358.

Vallerand, R.J. 2008. On the psychology of passion: In search of what makes people's lives most worth living. Canadian Psychology/Psychologie Canadienne 49(1): 1-13.

Vallerand, R.J. 2015. The Psychology of Passion: A Dualistic Model. New York: Oxford University Press.

Vallerand, R.J., Blanchard, C., Mageau, G.A., Koestner, R., Ratelle, C., Léonard, M. \& Marsolais, J. 2003. Les passions de l'ame: on obsessive and harmonious passion. Journal of Personality and Social Psychology 85(4): 756.

Vallerand, R.J. \& Rip, B.P. 2006. The self: Determinants, consequences, and processes. In The Fundamentals of Social Psychology, edited by R.J. Vallerand, 83-139. Montreal: Gaetan Morin.

Van Manen, M. 1990. Researching Lived Experience: Human Science for an Action Sensitive Pedagogy. Albany, NY: State University of New York Press.

Van Manen, M. 1994. Pedagogy, virtue, and narrative identity in teaching. Curriculum Inquiry 24(2): 135-170.

Vanevenhoven, J. 2013. Advances and challenges in entrepreneurship education. Journal of Small Business Management 51(3): 466-470.

Volery, T., Müller, S., Oser, F., Naepflin, C. \& del Rey, N. 2013. The impact of entrepreneurship education on human capital at upper-secondary level. Journal of Small Business Management 51(3): 429-446. 
Welpe, I.M., Spörrle, M., Grichnik, D., Michl, T. \& Audretsch, D.B. 2012. Emotions and opportunities: The interplay of opportunity evaluation, fear, joy, and anger as antecedent of entrepreneurial exploitation. Entrepreneurship Theory and Practice 36(1): 69-96.

Winkel, D. 2013. The changing face of entrepreneurship education. Journal of Small Business Management 51(3): 313-314.

Zigarmi, D., Nimon, K., Houson, D., Witt, D. \& Diehl, J. 2009. Beyond engagement:Toward a framework and operational definition for employee work passion. Human Resource Development Review 8(3): 300-326.

Muhammad Nizam Zainuddin

Centre of Excellence for Knowledge and Innovation Management (CEKIM)

Faculty of Management

Multimedia University

63100 Cyberjaya, Selangor, MALAYSIA.

E-Mail: Muhammad.nizam@mmu.edu.my

Dzulkifli Mukhtar (corresponding author) Faculty of Entrepreneurship and Business Universiti Malaysia Kelantan

16100 Kota Bharu, Kelantan, MALAYSIA.

E-Mail: dzulkifli@umk.edu.my

Norhafizah Abu Hasan

Centre of Value Creation and Human Well-being

Faculty of Economics and Management

Universiti Kebangsaan Malaysia

43600 UKM Bangi, Selangor, MALAYSIA.

E-Mail: norhafizah1@ukm.edu.my

Mohd Helmi Ali

Centre of Global Business and Digital Economy

Faculty of Economics and Management

Universiti Kebangsaan Malaysia

43600 UKM Bangi, Selangor, MALAYSIA.

E-Mail: mohdhelmiali@ukm.edu.my 